\title{
Effect of Different Substrate Supplements on Oyster Mushroom (Pleurotus spp.) Production
}

\author{
Jawad Ashraf ${ }^{1}$, Muhammad Asif Ali ${ }^{1}$, Waqas Ahmad ${ }^{1, *}$, Chaudhry Muhammad Ayyub ${ }^{1}$, Jamil Shafi $^{2}$ \\ ${ }^{1}$ Institute of Horticultural Sciences, University of Agriculture, Faisalabad (38040) Pakistan \\ ${ }^{2}$ Department of Plant Pathology, University of Agriculture Faisalabad (38040) Pakistan \\ *Corresponding Author: uaf_waqas@yahoo.com
}

Copyright (C) 2013 Horizon Research Publishing All rights reserved.

\begin{abstract}
To compare the effect of different agricultural wastes on growth and yield of mushroom production, three species of Pleurotus viz. P. sajor-caju $\left(\mathrm{V}_{1}\right)$, P. ostreatus $\left(\mathrm{V}_{2}\right)$, and $P$. djmor $\left(\mathrm{V}_{3}\right)$ were grown on three different substrates cotton waste $\left(\mathrm{T}_{1}\right)$, wheat straw $\left(\mathrm{T}_{2}\right)$ and paddy straw $\left(\mathrm{T}_{3}\right)$. The fastest spawn running, primordial initiation, harvesting stage, maximum number of fruiting bodies and maximum yield was observed in $T_{1}$ took minimum number of days $T_{3}$ showed maximum yield in $1^{\text {st }}$ flush showing no significant differences with treatment $T_{1}$ whereas $T_{1}$ took maximum yield in $2^{\text {nd }}$ flush and $3^{\text {rd }}$ flush. $P$. djmor showed the highest percentage of dry matter $(17.23 \%)$ and moisture content was found high in $P$. sajor-caju $(87.37 \%)$. P. ostreatus and $P$. sajor-caju showed the maximum protein $(27.23 \%)$ and fiber (26.28\%) contents. The ash contents were found maximum $P$. sajor-caju $(9.08 \%)$.The highest fat and carbohydrate contents were found in Pleurotus djmor (3.07\%) and $P$. djmor (37.69) respectively.
\end{abstract}

Keywords Oyster Mushroom, Substrates Selection, Morphological Parameters, Nutrition Analysis

\section{Introduction}

This Mushrooms are fleshy, spore-bearing reproductive structures of fungi grown on organic substrates and for a long time, have played an important role as a human food due to its nutritional and medicinal properties [1]. Mushrooms are a good source of protein, vitamins and minerals and are known to have a broad range of uses both as food and medicine. A high nutritional values of oyster mushrooms has been reported with protein $(25-50 \%)$, fat $(2-5 \%)$, sugars $(17-47 \%)$, mycocellulose (7-38\%) and minerals (potassium, phosphorus, calcium, sodium) of about 8-12\% [2]. Edible mushrooms are also rich in vitamins such as niacin, riboflavin, vitamin D, C, B1, B5 and B6 [3].

Oyster mushroom can be grown on various substrates including paddy straw, maize stalks/cobs, vegetable plant residues, bagasse etc. [4]. This has been reported to influence its growth, yield and composition [5, 6]. However, an ideal substrate should contain nitrogen (supplement) and carbohydrates for rapid mushroom growth [7]. Oyster mushroom cultivation can play an important role in managing organic wastes whose disposal has become a problem. Malnutrition is a problem in developing countries and these wastes can be recycled into food and environment may be less endangered by pollution [8]. Many of mushrooms pose a range of metabolites of intense interest to pharmaceutical e.g. antitumour, immunomodulatory, antigenotoxic, antioxidant, anti-inflammatory, hypocholesterolaemic, antihypertensive, antiplateletaggregating,antihyperglycaemic, antimicrobial and antiviral activities ( antitumour, immunomodulation agents, and hypocholesterol-aemic agents and food (e.g. flavor compound) industries [9]. Cultivated mushrooms have higher protein contents and minerals, low in fat and rich in vitamins $B$, vitamin $D$, vitamin $K$ and sometimes vitamins $A$ and $\mathrm{C}[10]$.

Pakistan is an agricultural country having $70 \%$ of its total population being pursued in agriculture directly or indirectly [11]. Agricultural waste material of wheat and paddy straw is reported to be about 11.0 and 3.2 million tonns per annum respectively, which increased to about 19.27, 5.16 and 1.35 million tonns of wheat, rice and maize straw during the year 1995-2000 respectively [12] that could be used for the cultivation of mushrooms. China is the major producer of oyster mushroom. The common method of cultivation of oyster mushroom in Zimbabwe is bag culture which requires bulk substrates. Tray cultivation has been used elsewhere with varying degree of success for the production of oyster and shiitake mushroom [13].

It is unfortunate that in Pakistan and Azad Kashmir, mushrooms have not caught the imagination of the public at large scale to become an important food item, perhaps the reason for not being taken up widely is non availability of mushrooms at low prices and lack of knowledge [14]. There is an urgent need to develop diversified agriculture in the Pakistan. The present work was carried out with objectives to evaluate the effect of basal substrate supplement such as paddy and wheat straw with cotton waste on oyster 
mushrooms production.

\section{Materials and Methods}

\subsection{Substrates and Spawn Preparation}

The study was conducted at Mushroom laboratory, Institute of Horticultural Sciences, University of Agriculture, Faisalabad during 2011-2012 for evaluation of three Pleurotus species viz. Pleurotus sajor-caju $\left(\mathrm{V}_{1}\right)$ Pleurotus ostreatus $\left(\mathrm{V}_{2}\right)$, and Pleurotus djmor $\left(\mathrm{V}_{3}\right)$ on three different substrates i.e. cotton waste (CW), paddy straw (PS) and wheat straw (WS). Species were maintained on Malt Extract Agar medium (MEA) which had following constituents; malt extract (20 gm), dextrose (20 gm), agar (20 gm), peptone (1 gm) and distilled water (1 liter). After autoclaving at $15 \mathrm{psi}$ for 15 minutes, the $\mathrm{pH}$ of the medium was 6.5. Plugs of $5 \mathrm{~mm}$ diameter were cut from the periphery of the actively growing mycelial colony, transferred to fresh (MEA) agar plates and incubated at $25^{\circ} \mathrm{C}$. Sorghum grains were boiled in water $(300 \mathrm{~g} / \mathrm{L})$ for 15 minutes, excess water was drained off, then calcium carbonate and gypsum (1.5\% of each) added and mixed thoroughly. The grains were filled into 0.251 milk bottles which were then plugged with cotton wool, covered with an aluminum foil cap and autoclaved at $121^{\circ} \mathrm{C}(15 \mathrm{psi})$ for half an hour. When cooled, the grains were inoculated with $1 \mathrm{~cm}$ plugs from agar cultures or grain spawn of both strains of Pleurotus spp., and incubated at $25^{\circ} \mathrm{C}$ for two weeks.

\subsection{Substrate Preparation}

Substrates were soaked in water and 2 percent lime was mixed in cotton waste to maintain its $\mathrm{pH}$. After soaking, the substrates were piled up and covered with polythen sheet. Substrates were allowed to ferment for 4 days. Substrates then spread on floor for evaporation of excess moisture and which was finally maintained at $70 \%$. Substrates were filled in polypropylene bags $(6 \times 8)$ and bags mouths were loosely tied with rubber band.

\subsection{Pasteurization}

The bags were pasteurized, cooled for one day was inoculated with spawn at the rate of $10 \mathrm{gm}$ per bag. During spawn running the temperature in growth room was controlled between $22-26{ }^{\circ} \mathrm{C}$ for spawn running. The required humidity was maintained between $70-80 \%$ by sprinkling water on the floor several times a day. During spawn running the temperature in growth room was controlled between $22-26{ }^{0} \mathrm{C}$ for spawn running. The required humidity was maintained between $70-80 \%$ by sprinkling water on the floor several times a day.
After completion of spawn running the temperature of growing room maintained between $16-25^{\circ} \mathrm{C}$. Fruit body was started as soon as the substrate was fully impregnated with mycelial growth. The humidity of the growing room was maintained between $80-90 \%$ by sprinkling water on floor and moisture requirements of the bags was accomplished by sprinkling water on them thrice a day using sprinkler. After the completion of previous step, later in case of cropping, moisture content of the substrate were visually checked daily. However, during the cropping period the bags were sprinkled with water twice a day.

\subsection{Morphological Parameter}

The data was collected and observations were made on the following parameters: Numbers of days taken for the completion of mycelial growth after spawning, time taken for primordia formation after the completion of mycelial growth, time taken to reach maturity stage after primordia formation, total number of fruit bodies, total number of flushes and yield of each bag and total yield $(\mathrm{g})$ of the mushrooms were calculated after the completion of cropping period.

\subsection{Chemical Analysis}

Chemical study of mushroom for Moisture content (\%), dry matter (\%), crude protien (\%), crude fiber (\%), ash content (\%), crude fat (\%)and total carbohydrate (\%) were analyzed according to standard method Helrich, [15] by using the following formula;

$$
\begin{aligned}
& \text { Moisture }(\%)=\frac{\text { Initial Wt.-final Wt. }}{\text { Wt. of sample }} \times 100 \\
& \operatorname{Dry} \text { matter }(\%)=\frac{\text { Wt. of an oven dried sample }}{\text { Wt. of sample }} \times 100 \\
& \mathrm{~N}(\%)=\frac{(\mathrm{ml} \text { of } \operatorname{acid} \times \operatorname{acid} \mathrm{N}))}{\text { Wt. of sample }} \times 100 \\
& \text { Crude fiber }(\%)= \\
& \text { Wt. of an oven dried sample-Wt. of ash } \\
& \text { Wt. of sample }
\end{aligned}
$$

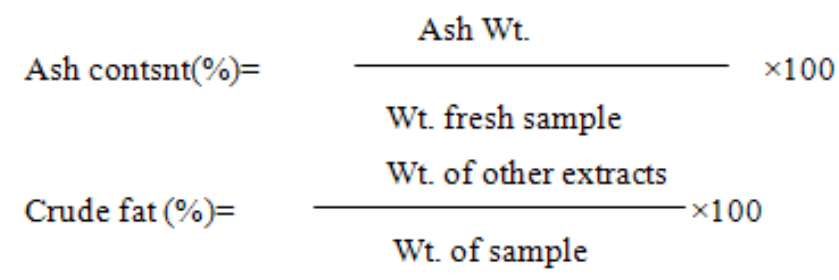

Crude carbohydrate $(\%)=\{100$ - $($ crude protein + crude fat + crude fiber +crude ash $)\}$

\subsection{Statistical Analysis}

\subsection{Cropping and Watering}


Both factorial and complete randomized design (CRD) were used to evaluate the growth of Pleurotus Spp. on different substrates. Analysis of variance (ANOVA) techniques was employed to test the overall significance of data while the least significance difference (LSD) test was used to compare the differences among varieties means [16].

\section{Results}

\subsection{Spawn Running}

Highly significant results were observed among treatments in terms of days taken for spawn running of three Pleurotus spp. (P. sajor-caju, P. ostreatus and P. djmor). These species behaved drastically on different growing media in completing their mycelial growth and treatment $x$ variety interaction was highly significant. $T_{1}$ took minimum number of days $16.20 \pm 0.59$ whereas treatments $T_{3}$ and $T_{2}$ showed same level of significance with number of days $18.33 \pm 0.77$ and $18.47 \pm 0.55$ respectively to complete mycelial growth but differ significantly from $\mathrm{T}_{1}$. Among the species, $P$. ostreatus took minimum number of days $16.27 \pm$ 0.63 . Species $P$. sajor-caju and $P$. djmor showed same level of significance with $18.07 \pm 0.69$ and $18.67 \pm 0.61$ days respectively to complete mycelial growth but both differ significantly from $P$. ostreatus (Table 1). Among interaction studies, $P$. ostreatus was recorded best in terms of time taken (in days) for accomplishment of spawn running by taking minimum number of days $13.80 \pm 0.37$ while grown on $\mathrm{T}_{1}$ (Fig 1A).

\subsection{Emergence of Primordial}

Treatments showed non-significant results in terms of days taken for emergence of primordia after completion of mycelial growth. $\mathrm{T}_{1}$ took minimum number of days $4.20 \pm$ 0.34 followed by $\mathrm{T}_{2}$ and $\mathrm{T}_{3}$ with $4.67 \pm 0.30$ and $4.73 \pm 0.33$ days respectively to reach primordia initiation. Among the species, $P$. ostreatus took minimum number of days $3.73 \pm$ 0.32. P. sajor-caju and P. djmor showed same level of significance with $4.73 \pm 0.32$ and $5.13 \pm 0.24$ days respectively (Table 1) to complete emergence of primordia but both differ significantly from $P$. ostreatus. P. ostreatus was recorded best in terms of time taken (in days) for emergence of primordia by taking minimum number of days $2.80 \pm 0.37$ while grown on $\mathrm{T}_{1}$ (Fig 1B).

\subsection{Harvesting Stage}

Pleurotus spp behaved significantly on different growing media to attain harvesting stage. $T_{1}$ took minimum number of days $2.60 \pm 0.16$ followed by $\mathrm{T}_{2}$ and $\mathrm{T}_{3}$ with $2.67 \pm 0.21$ and $2.87 \pm 0.24$ days respectively. Among the species, $P$. ostreatus took minimum number of days $2.40 \pm 0.19$ and showed significant results with $P$. djmor which reached the harvesting stage in $3.07 \pm 0.18$ days after primordia initiation.
$P$. sajor-caju showed non-significant behavior with both $P$. ostreatus and $P$. djmor by taking $2.67 \pm 0.21$ days (Table 1C).

\subsection{Fruiting Bodies}

$\mathrm{T}_{1}$ took maximum number of fruit bodies $4.33 \pm 0.42$ followed by $\mathrm{T}_{2}$ and $\mathrm{T}_{3}$ with the number of fruit bodies $3.80 \pm$ 0.30 and $3.53 \pm 0.24$ respectively. Among the species, $P$. ostreatus took maximum number of fruit bodies $4.93 \pm 0.28$. Species $P$. djmor and $P$. sajor-caju showed same level of significance with number of fruit bodies, $3.53 \pm 0.31$ and $3.20 \pm 0.22$ respectively (Table 1) but both differ significantly from $P$. ostreatus. $P$. ostreatus was recorded best in terms of number of fruit bodies by taking a maximum of $6.00 \pm 0.32$ on $T_{1}$ respectively.

\subsection{Yield of Mushroom in $1^{\text {st }}$ Flush (g)}

Treatments in the first flush showed significant difference in terms of yield. These Pleurotus spp. also behaved significantly on different growing media to produce $1^{\text {st }}$ flush. Treatment $\times$ variety interaction was highly significant. Among the treatments, $\mathrm{T}_{3}$ took maximum yield $21.53 \pm 0.83$ $\mathrm{g}$ in $1^{\text {st }}$ flush showing no significant differences with treatment $\mathrm{T}_{1}$ which produced $21.40 \pm 0.75 \mathrm{~g}$. $\mathrm{T}_{2}$ showed significant results from $T_{3}$ and $T_{1}$ by producing $19.80 \pm 1.15$ $\mathrm{g}$ in $1^{\text {st }}$ flush. Among the species, $P$. ostreatus took maximum yield $23.73 \pm 0.56$ g. $P$. sajor-caju and $P$. djmor showed same level of significance by yielding $19.60 \pm 1.11 \mathrm{~g}$ and $19.40 \pm 0.58 \mathrm{~g}$ respectively in $1^{\text {st }}$ flush but both differ significantly from $P$. ostreatus (Table 1). Among interaction studies, both $P$. ostreatus grown on $\mathrm{T}_{2}$ and $P$. sajor-caju $\left(\mathrm{V}_{1}\right)$ grown on $\mathrm{T}_{3}$ were recorded best in terms of yield in $1^{\text {st }}$ flush by producing $25.20 \pm 1.11$ and $25.20 \pm 0.37$ respectively (Fig $1 \mathrm{E})$.

\subsection{Yield of Mushroom in $2^{\text {nd }}$ Flush (g)}

In $2^{\text {nd }}$ flush $\mathrm{T}_{1}$ took maximum yield $14.73 \pm 0.57 \mathrm{~g}$ in $2^{\text {nd }}$ flush. $T_{3}$ and $T_{2}$ showed same level of significance by producing $9.93 \pm 0.34 \mathrm{~g}$ and $9.13 \pm 0.38 \mathrm{~g}$ in $2^{\text {nd }}$ flush but both differ significantly from $\mathrm{T}_{1}$. Among the species, $P$. ostreatus took maximum yield $11.87 \pm 0.81 \mathrm{~g}$ followed by $P$. djmor which yielded $11.47 \pm 0.92 \mathrm{~g}$ having no significant differences with $P$. ostreatus. $P$. sajor-caju differs significantly from $P$. ostreatus and $P$. djmor by producing a lower yield of $10.47 \pm 0.57 \mathrm{~g}$ in $2^{\text {nd }}$ flush (Table 1). Among interaction studies, both $P$. djmor grown on $\mathrm{T}_{1}$ and $P$. ostreatus grown on $\mathrm{T}_{1}$ were recorded best in terms of yield in $2^{\text {nd }}$ flush by producing $15.80 \pm 1.16 \mathrm{~g}$ and $15.80 \pm 0.49 \mathrm{~g}$ respectively (Fig 1F).

\subsection{Yield of Mushroom in $3^{\text {rd }}$ Flush (g)}

Treatments showed highly significant results in terms of yield in $3^{\text {rd }}$ flush. $T_{1}$ (took maximum yield $7.53 \pm 0.70 \mathrm{~g}$ in $3^{\text {rd }}$ 
flush. $T_{3}$ and $T_{2}$ showed same level of significance by producing $4.60 \pm 0.43 \mathrm{~g}$ and $4.00 \pm 0.28 \mathrm{~g}$ in $3^{\text {rd }}$ flush but both differ significantly from $\mathrm{T}_{1}$. Among the species, $P$. ostreatus (took maximum yield $6.07 \pm 0.61 \mathrm{~g}$ and showed significant results with $P$. sajor-caju which yielded $4.67 \pm$ $0.42 \mathrm{~g}$ in $3^{\text {rd }}$ flush. Specie $P$. djmor showed non-significant behavior with both $P$. ostreatus and $P$. sajor-caju by producing $5.40 \pm 0.80 \mathrm{~g}$ in $3^{\text {rd }}$ flush (Table 1). Among interaction studies, both $P$. djmor grown on $\mathrm{T}_{1}$ and $P$. ostreatus grown on $\mathrm{T}_{1}$ were recorded best in terms of yield in $3^{\text {rd }}$ flush by producing $9.00 \pm 1.26 \mathrm{~g}$ and $9.00 \pm 0.45 \mathrm{~g}$ respectively (Fig 1G).

\subsection{Total Yield (g)}

In terms of total yield, a highly significant results were recorded in the treatments of Pleurotus spp. $\mathrm{T}_{1}$ produced maximum yield of $41.27 \pm 1.64 \mathrm{~g}$ followed by $\mathrm{T}_{3}$ and $\mathrm{T}_{2}$ with total yield of $35.87 \pm 1.43 \mathrm{~g}$ and $32.87 \pm 1.46 \mathrm{~g}$ respectively (Table 1). Among the species, $P$. ostreatus took maximum yield $41.60 \pm 1.49$ g. Species $P$. sajor-caju and $P$. djmor (showed same level of significance by yielding total of 34.60 $\pm 1.70 \mathrm{~g}$ and $33.80 \pm 1.30 \mathrm{~g}$ respectively but both differ significantly from $P$. ostreatus. $P$. ostreatus was recorded best in terms of total yield (g) by taking a maximum of 49.00 \pm 0.45 while grown on $T_{1}$ (Fig $1 \mathrm{H}$ ).

\subsection{Moisture Contents}

The moisture content was found highest in $P$. sajor-caju ( $87.37 \%$ ) followed by $P$. ostreatus $(86.27 \%)$ and $P$. djmor
(82.77\%). The variation in moisture content among different species of mushroom is highly significant (Fig 2A).

\subsection{Dry Matter}

$P$. djmor showed the highest percentage of dry matter $(17.23 \%)$ whereas, the followed by P. ostreatus $(13.73 \%)$ and $P$. sajor-caju $(12.63 \%)$ respectively (Fig $2 \mathrm{~B})$.

\subsection{Protein, Fiber, Ash, Fats and Carbohydrate Contents}

Crude protein was found maximum in $P$. ostreatus (27.23\%) and minimum in $P$. djmor $(24.83 \%)$ and found in Pleurotus sajor-caju (25.24\%) range between P. ostreatus and P. sajor-caju (Fig 2C). Fiber content data described that Pleurotus sajor-caju showed maximum fiber content (26.28\%) followed by P. ostreatus (24.53\%) and Pleurotus djmor (22.03\%) respectively (Fig 2D). Ash contents in three varieties of oyster mushroom were found statistically highly significant (Fig 2C). The result showed that the ash content found highest in P. sajor-caju (9.08\%) while in P. ostreatus the ash content was recorded minimum (6.76\%) and the ash content of P. djmor (8.35\%) found between P. sajor-caju and $P$. ostreatus (Fig 2E). The total fat content was found highest in Pleurotus djmor $(3.07 \%)$ as compared to the other two as in P. sajor-caju found (2.47\%) and in P. ostreatus $(2.37 \%)$ respectively (Table 2 ). Results showed that the carbohydrate content found highest in P.djmor (37.69\%) followed by $P$. sajor-caju $(37.22 \%)$ and $P$. ostreatus (36.74\%) respectively (Fig $2 \mathrm{G})$.

Table 1. Morphological parameters of three varieties of Oyster mushroom grown under domestic conditions

\begin{tabular}{|c|c|c|c|c|c|c|c|c|}
\hline Treatments & $\begin{array}{c}\text { spawn } \\
\text { running }\end{array}$ & $\begin{array}{c}\text { primordia } \\
\text { emergence }\end{array}$ & $\begin{array}{c}\text { Harvesting } \\
\text { stage }\end{array}$ & $\begin{array}{c}\text { Fruiting } \\
\text { bodies }\end{array}$ & $1^{\text {st }}$ flush $(\mathrm{g})$ & $2^{\text {nd }}$ flush $(\mathrm{g})$ & $3^{\text {rd }}$ flush $(\mathrm{g})$ & $\begin{array}{c}\text { Total yield } \\
(\mathrm{g})\end{array}$ \\
\hline $\begin{array}{c}\mathrm{T}_{1} \text { (Cotton } \\
\text { waste) }\end{array}$ & $16.20 \pm 0.59 \mathrm{~B}$ & $4.20 \pm 0.34 \mathrm{~A}$ & $2.60 \pm 0.16 \mathrm{~A}$ & $4.33 \pm 0.42 \mathrm{~A}$ & $21.40 \pm 0.75 \mathrm{~A}$ & $14.73 \pm 0.57 \mathrm{~A}$ & $7.53 \pm 0.70 \mathrm{~A}$ & $\begin{array}{c}41.27 \pm 1.64 \\
\mathrm{~A}\end{array}$ \\
\hline $\begin{array}{c}\mathrm{T}_{2} \text { (Wheat } \\
\text { straw) }\end{array}$ & $18.47 \pm 0.55 \mathrm{~A}$ & $4.67 \pm 0.30 \mathrm{~A}$ & $2.67 \pm 0.21 \mathrm{~A}$ & $3.80 \pm 0.30 \mathrm{~A}$ & $19.80 \pm 1.15 \mathrm{~B}$ & $9.13 \pm 0.38 \mathrm{~B}$ & $4.00 \pm 0.28 \mathrm{~B}$ & $32.87 \pm 1.46 \mathrm{C}$ \\
\hline $\begin{array}{c}\mathrm{T}_{3} \text { (Paddy } \\
\text { straw) }\end{array}$ & $18.33 \pm 0.77 \mathrm{~A}$ & $4.73 \pm 0.33 \mathrm{~A}$ & $2.87 \pm 0.24 \mathrm{~A}$ & $3.53 \pm 0.24 \mathrm{~A}$ & $21.53 \pm 0.83 \mathrm{~A}$ & $9.93 \pm 0.34 \mathrm{~B}$ & $4.60 \pm 0.43 \mathrm{~B}$ & $35.87 \pm 1.43 \mathrm{~B}$ \\
\hline
\end{tabular}

Table 2. Chemical analysis of three varieties of Oyster mushroom grown under domestic conditions

\begin{tabular}{|c|c|c|c|c|c|c|c|}
\hline Treatments & $\begin{array}{c}\text { Moisture } \\
\text { content (\%) }\end{array}$ & Dry matter \% & protein $\%$ & Fiber $\%$ & Ash $\%$ & fat $\%$ & Carbohydrate $\%$ \\
\hline $\begin{array}{c}\mathrm{T}_{1} \text { (Cotton } \\
\text { waste) }\end{array}$ & $86.27 \pm 0.033 \mathrm{~A}$ & $13.73 \pm 0.03 \mathrm{~B}$ & $27.23 \pm 0.056 \mathrm{~A}$ & $24.53 \pm 0.264 \mathrm{~B}$ & $6.76 \pm 0.087 \mathrm{C}$ & $2.37 \pm 0.251 \mathrm{~B}$ & $36.74 \pm 1.13 \mathrm{~A}$ \\
\hline $\begin{array}{c}\mathrm{T}_{2} \text { (Wheat } \\
\text { straw) }\end{array}$ & $87.37 \pm 0.088 \mathrm{~B}$ & $12.63 \pm 0.088 \mathrm{C}$ & $25.24 \pm 0.055 \mathrm{~B}$ & $26.28 \pm 0.113 \mathrm{~A}$ & $9.08 \pm 0.046 \mathrm{~A}$ & $2.47 \pm 0.045 \mathrm{~B}$ & $37.22 \pm 1.23 \mathrm{~A}$ \\
\hline $\begin{array}{c}\mathrm{T}_{3} \text { (Paddy } \\
\text { straw) }\end{array}$ & $82.77 \pm 0.033 \mathrm{C}$ & $17.23 \pm 0.033 \mathrm{~A}$ & $24.83 \pm 0.043 \mathrm{C}$ & $22.03 \pm 0.062 \mathrm{C}$ & $8.35 \pm 0.081 \mathrm{~B}$ & $3.07 \pm 0.061 \mathrm{~A}$ & $37.69 \pm 1.49 \mathrm{~A}$ \\
\hline
\end{tabular}




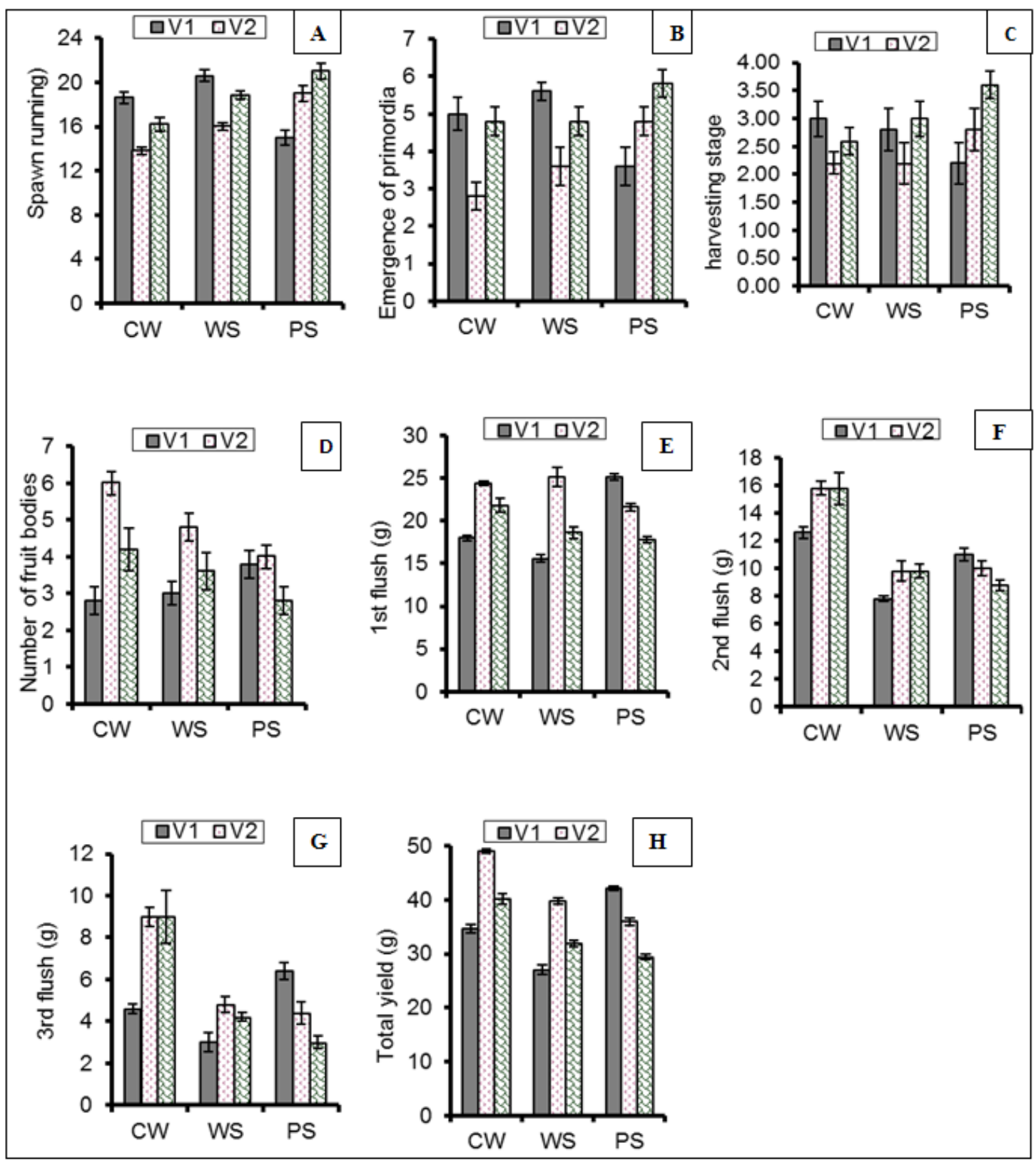

Figure 1. Effect of different substrate on growth parameters of Oyster Mushroom (pleurotus spp.) 


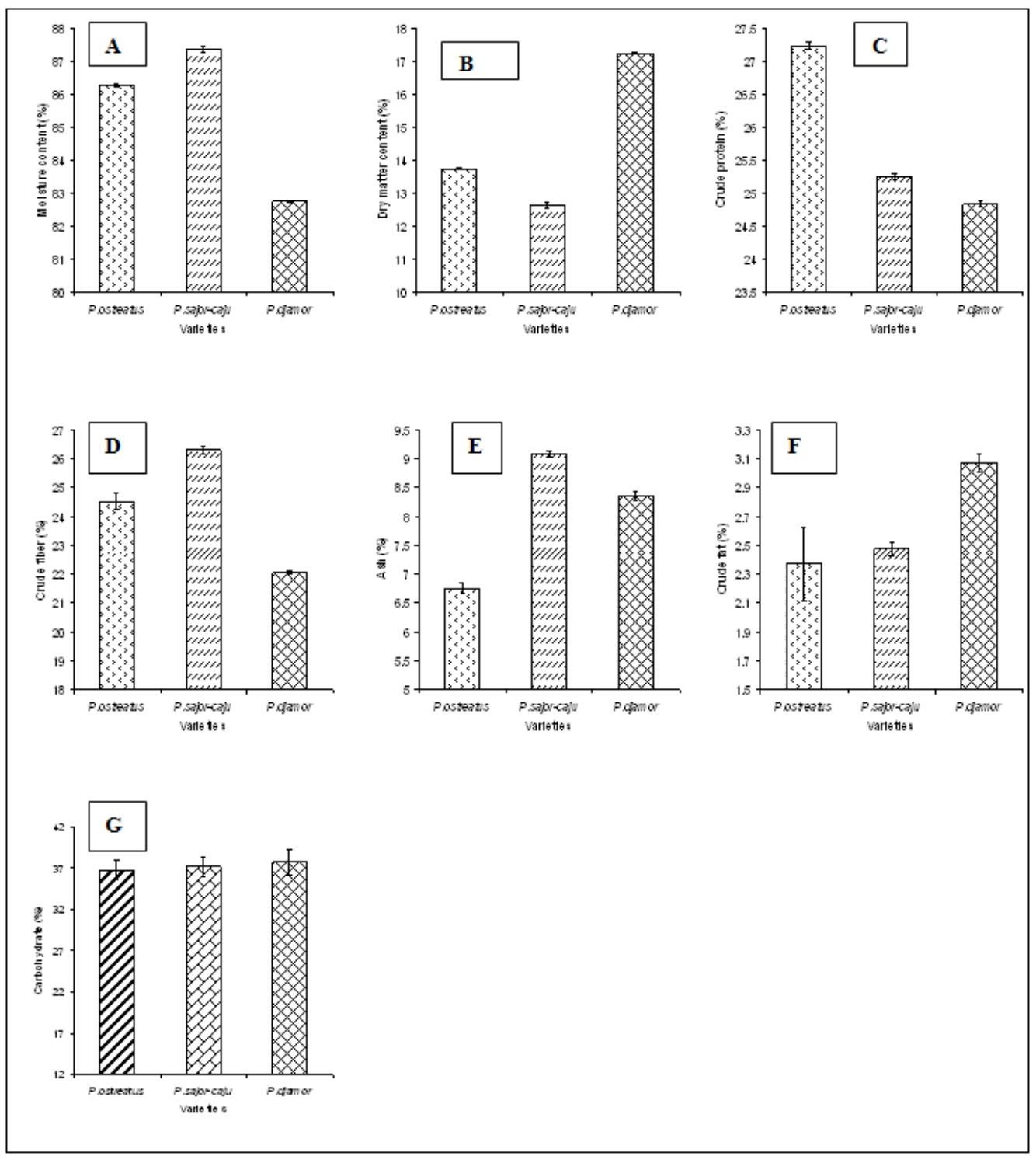

Figure 2. Chemical analysis of Oyster Mushroom (pleurotus spp.)

\section{Discussion}

The Various crop residues can be used in producing Oyster mushrooms either as main substrates or in combinations with supplements. The different strains of oyster mushroom (Pleurotus spp.) on cotton waste showed high production in the treatments. The mycelial growth in wet composts was improved when packed less density, possibly because of improved aeration. Most rapid colonization occurs within the temperature range $22-27^{\circ} \mathrm{C}$. A wide range of organic waste materials have been proposed for mushroom cultivation. Wheat straw is one example and its $25 \%$ supplementation with olive mill effluent gives economic mushroom yield [17].

Mendez [18] grew Pleurotus ostreatus on maize straw and analyzed the mushroom fruiting bodies for three flushes for amino acid profile and nitrogen contents. They observed no significant effect of substrate for these attributes but nitrogen contents of fruiting bodies increased from 4.13 gram to 5.74 gram in $1^{\text {st }}$ to $3^{\text {rd }}$ flush respectively. Weed plants such as Lantana camara, Teohrosia purpurea, Cassia sophera, Ageratum conzoides, Parthenium argentatum, Sida acuta and Leonotis spp. encountered the problem of low yield on $2^{\text {nd }}$ flush for these substrates but they suggested the addition of rice straw in the weed plants based substrate to overcome the problem [19]. This approach can overcome the problem of low yield in later flushes to great extent. Different methods of compost preparation and lime concentration has the maximum number of flushes and the highest yield $(295 \mathrm{~g} / 1.5 \mathrm{~kg}$ substrate) in Pleurotus sajor-caju obtained from wetting wheat straw $+2 \%$ lime concentration [20].

Crude protein was found maximum in $P$. ostreatus (27.23\%) and minimum in $P$. djmor (24.83\%) and found in Pleurotus sajor-caju (25.24\%) range between P. ostreatus and P. sajor-caju. Materials rich in nitrogenous sources give good mushroom yield as given by the soybean. Materials like 
coir pith, dried mango leaves, wood shavings, cotton waste, sugarcane baggas, coconut coir, water hyacinth, Cassia sophera, Lantana camara, Leonits spp., groundnut haulms, pigeanpea stalks, sawdust and coffee husk etc. were utilized by many researchers for cultivation of mushroom $[21,6$ ). The artificial application of nitrogen rich source during the mycelial growth stage gives very good results regarding early primordial initiation. It can be concluded that a nitrogen rich source application during spawn running speeds up the fungal mycelium growth and gives early primordial emergence.

The large sized fruit bodies are considered to be of good quality and rated highly in mushroom production [22] but this as an inferior quality since such fruit bodies tend to break during packaging thereby reducing their quality [22]. Dundar [23]cultivated Pleurotus ostreatus, Pleurotus eryngii and Pleurotus sajor-caju on wheat stalk substrate. Pleurotus eryngii, Pleurotus ostreatus and Pleurotus sajor-caju took 85.27 days, 82.64 days and 67.46 days respectively. It was observed that strip opening, forming big holes, or half opening polypropylene bags result in higher yield and larger sporophores. There are many factors which affect the yield, compost preparation moisture level and temperature fluctuation cause low yield. When $\mathrm{pH}$, moisture level and $\mathrm{C} / \mathrm{N}$ ratio is best then maximum number of pinheads and mushrooms formed.

Baysal [24] investigated paper waste supplemented with rice husk, chicken manure and peat for Pleurotus ostreatus cultivation. Highest yield for fresh weight was recorded as 350.2 grams in the substrate containing $20 \%$ rice husk. Mushrooms are a potential source of total carbohydrates in the range of $42.62-66.78 \mathrm{~g} / 100 \mathrm{~g}$ and of protein in the range of 27.95-38.89 g/100g depending upon the species. Very low fat contents $1.34-6.45 \mathrm{~g} / 100 \mathrm{~g}$ makes mushroom a best diet for people suffering from heart diseases [25]. Chang [9] cultivated Agaricus officinalis L. and obtained $6.7 \mathrm{~kg} / \mathrm{m}^{2}$ of yield from this substrate but when they added appropriate quantity of cotton seed hulls then the yield (fresh weight) increased from $6.7 \mathrm{~kg} / \mathrm{m}^{2}$ to $9.8 \mathrm{~kg} / \mathrm{m}^{2}$.

The fiber content in $P$. djmor (17.2\%) was much higher than those in white and yellow winter mushrooms $(F$. velutipes) at $16.0 \%$ and $17.0 \%$, respectively [26]. Oyster mushrooms have rich in fiber and low in fat contents this character is highly beneficial for heart patients. Bultosa [27] found the highest ash content in $P$. sajor-caju grown on bean straw and wheat straws and the lowest content was for $P$. florida grown on bean straw.

Oyster mushrooms have rich in fiber and low in fat contents this character is highly beneficial for heart patients. The study also indicates that the nutritional value of oyster mushroom differs but all species are healthful with abundant amount of fiber and protein and other essential nutrients. Mona [28] investigated nutritional analysis and enzyme activities of Pleurotus ostreatus cultivated on citrus limonium and Carica papaya wastes and they concluded that fruit bodies containing $26.0-31.5 \%$ digestible protein, 20.9 $-33.0 \%$ total soluble carbohydrates and $2.0-5.9 \%$ fat (on dry basis). Several white rot fungi are edible mushrooms have been successfully cultivated at commercial level worldwide using lignocellulose wastes as substrates for their cultivation highest percentage of fat content [29].

Dundar [21] found that the carbohydrate values of $P$. sajor-caju, $P$. ostreatus and $P$. eryngii are $37.72,37.87$ and $39.85(\mathrm{~g} / 100 \mathrm{~g}$ dried matter) respectively. The carbohydrate content found in all varieties of oyster mushroom almost showed same result and variation in carbohydrate content is not statistically significant. The analysis shows that all three varieties of oyster mushroom contain excellent nutritional value for human and among three substrates cotton waste supplemented substrate was found excellent material for mushroom production. Protein, fiber and carbohydrates are essential nutrition components and deficiency of these components is serious issue especially in developing countries. So mushroom is essential food to maintain the malnutrition problem in such countries. Mushrooms have long been used as food or food flavoring material due to their unique flavor. Pakistan has a large edible mushroom potential and can become an important exporter of wild mushrooms. This work intended to assess the species which gives good production and high biological efficiency on commercial basis.

\section{Conclusion}

The study was conducted for evaluation of three Pleurotus species viz. Pleurotus sajor-caju $\left(\mathrm{V}_{1}\right)$ Pleurotus ostreatus $\left(\mathrm{V}_{2}\right)$, and Pleurotus djmor $\left(\mathrm{V}_{3}\right)$ on three different substrates i.e. cotton waste (CW), paddy straw (PS) and wheat straw (WS). Among all the treatments cotton west was found most favourable for mashroom cultivation.

\section{REFERENCES}

[1] O. K. Etich, O. I. Nyamangyoku, O. I. Rono, J. J. Niyokuri, A. N. Izamuhaye. Relative performance of Oyster Mushroom (Pleurotus florida) on agroindustrial and agricultural substrate, International Journal of Agronomy and Plant Production, Vol.4, No.1, 109-116, 2013.

[2] R.P. Stanley. Enumerative combinatorics, Cambridge university press, Vol. 49, 2011.

[3] A. A. Syed, J. A. Kadam, V. P. Mane, S. S. Patil, M. M. V. Baig. 2009. Biological efficiency and nutritional contents of Pleurotus florida (Mont.) Singer cultivated on different Agro-wastes, Natural Science, Vol.7, No.1, 44- 48. 2009.

[4] S. Hassan, A. Y. Mohammad, K. Kiramat. Cultivation of the oyster mushroom (Pleurotus ostreatus (Jacq.) P. Kumm.) in two different agroecological zones of Pakistan, African Journl of Biotechnology, Vol.10, 183-188, 2011.

[5] S. M. Iqbal, C. A. Rauf, M. I. Sheikh. Yield performance of oyster mushroom on different substrate, International Journal of Agriculture and Biology, Vol.7, No.6, 900-903, 2005. 
[6] J. W. Kimenju, G. O. M. Odero, E.W. Mutitu, P.M. Wachira, R. D. Narla, W.M. Muiru. Suitability of locally available substrates for oyster mushroom cultivated in Kenya, Asian Journal of Plant Science, Vol. 6, No.2, 648-652, 2009.

[7] K. B. Khare, J. M. Mutuku, O. S. Achwania, D.O. Otaye. Production of two oyster mushrooms, Pleurotus sajor-caju and $P$. florida on supplemented and un-supplemented substrates, International Journal of Agriculture and Applied Sciences, Vol. 6, 4-11, 2010.

[8] A. Eswaran, R. Ramabadran. Studies on some physiological, cultural and post harvest aspects of oyster mushroom, Pleurotus ostreatus, Tropical Agricultural Research Journal, Vol.12, 360-374, 2000.

[9] S. T. Chang. Mushroom cultivation using the "ZERI" principle: potential for application in Brazil, Micologia Aplicada Internatonal, Vol.19, No.2, 33-34, 2007.

[10] P. Manzi, A. Aguzzi, L. Pizzoferrato. Nutritional value of mushrooms widely consumed in Italy, Food Chemistry, $73: 321,2001$.

[11] Anonymous, Agriculture in Pakistan, Online available from http: // www. pakistaneconomist.com/ issue 2001 / issue37/ i\&e 4.

[12] M. Sarwar, M. A. Khan, Z. Iqbal. Feed Resourses for Livestock in Pakistan, International Journal of Agriculture and Biology, Vol. 4, No.1, 186-92, 2002.

[13] P. Oei. Mushroom cultivation-Appropriate Technology for Mushroom Growers $3^{\text {rd }}$ Ed. Backhuys Publishers, Netherland, 2003.

[14] K.C. Helrich. Official methods of Analysis of the AOAC. Association of Official Analytical Chemists Inc., Vol. 2, No.15, 1990.

[15] Z. A. Shah. M. Ashraf, M. I. Ch. Comparative study on cultivation and yield performance of oyster mushroom on different substrates, Pakistan Journal of Nutrition, Vol.3, 158-160, 2004.

[16] R. G. D. Steel, J. H. Torrie, D. A. Dickey. Principlęs and Procedures of Statistics. A biometrical approach. 3 Ed., McGraw Hill Book Co., USA, 1997.

[17] E. Kalmis, N. Azhar, H. Yildiz, F. Kalyonus. Feasibility of using olive mill effluent (OME) as a wetting agent during the cultivation of oyster mushroom, Pleurotus ostreatus, on wheat straw, Bioresearch Technology, Vol.99, 164-169, 2008.

[18] L. A. Mendez, C. A. S. Castro, R. B. Casoo, C. M. C. Leal. Effect of substrate and harvest on the amino acid profile of
Oyster mushroom (Pleurotus ostreatus), Journal of Food Comp. Ana, Vol.18, 447-450, 2005

[19] N. Das, M. Mukherjee, Cultivation of Pleurotus ostreatus on weed plants, Bioresearch Technology, Vol.98, 2723-2726, 2007.

[20] M. N. Shahid, N. A. Abbasi, N. Saleem. Studied the effect of different methods of compost preparation and lime concentration on the yield of Pleurotus sajor-caju, International Journal of Agriculture and Biology, 1560-1585, 2006.

[21] L. S. Fan, A. Pandey, A. Vandenberghe, C. R. Soccol. Effect of caffeine and tannins on cultivation and fructification of Pleurotus on coffee husks, Brazilian Journal of Microbiology, Vol.37, No.4, 420-424, 2006.

[22] B. O. Onyango, V.A Palapala, P. F. Arama, S. O. Wagai, B. M. Gichimu. Suitability of selected supplemented substrates for cultivation of Kenyan native wood ear mushrooms (Auricularia auricula), American Journal of Food Technology, Vol.6, 395-403, 2011.

[23] A. Dundar, H. Acay, A. Yildiz. Yield performances and nutritional contents of three oyster mushroom species cultivated on wheat stalk, African Journal of Biotechnology, Vol.7, No.19, 3497-3501, 2008.

[24] E. Baysal, H. Peker, M. K. Yalinkilic, A. Temiz. Cultivation of Oyster Mushroom on waste paper with some added supplementary materials, Bioreserch Technology, Vol.89, 95-97, 2003.

[25] S. Beluham, A. Ranogajec. Chemical composition and non-volatile components of Croatian wild edible mushrooms, Food Chemistry, Vol.124, No.3, 1076-1082, 2011.

[26] J. Yang, H. Lin, J. Mau. Non-volatile taste components of several commercial mushrooms, Food Chemistry Vol.72, 465-471, 2001

[27] G. Bultosa, H. W. Michael, L. M. Pant. Nutritional contents of three edible oyster mushrooms grown on two substrates at haramaya, Ethiopia, and sensory properties of boiled mushroom and mushroom sauce, International Journal of Food Science and Technology, Vol.46, 732-738, 2011.

[28] M. R. Mona, H. M. Abdou. A. E. Mahmoud, M. U. Nooman. Nutritional analysis and enzyme activities of Pleurotus ostreatus cultivated on Citrus limonium and Carica papaya wastes, Australian Journal of Basic and Applied Science, Vol.3, No.4, 3352-3360, 2009.

[29] A. Ingale, A. Ramteke. Studies on cultivation and biological efficiencies of mushrooms grown on different agro residues, Innovative Rom. Food Biotechnology, Vol. 6, 25-28, 2010. 